\title{
Surviving "Los Sures": An anthropological reflection on the Nuyoricans lived experiences in South Williamsburg, Brooklyn and the current urban context of gentrification in New York City \\ Sobreviviendo "Los Sures": Una reflexión antropológica sobre las experiencias de vida de los Nuyoricans en South Williamsburg, Brooklyn, y el actual contexto de gentrificación urbana en Nueva York
}

\author{
Victor Vazquez ${ }^{1}$ \\ https://orcid.org/0000-0002-1065-9410 \\ Ashley McAfee ${ }^{2}$ \\ https://orcid.org/0000-0002-7492-1254
}

Primera versión recibida: 6 de abril de 2021 Última versión recibida: 27 de septiembre de 2021

\section{Abstract}

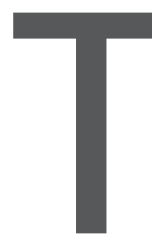

he following article presents an anthropological and historical reflection on the Puerto Rican inner-city neighborhood better known as "Los Sures" in South Williamsburg, Brooklyn, New York City (NYC). The analysis will explore the contemporary academic discussion regarding the following concepts: poverty, the welfare State, the discourse surrounding welfare recipient's culture, inner-city living conditions, and the current context of gentrification. Methodologically, the article presents an ethnographic reflection based on fieldwork experiences and interviews conducted on residents of the previous "Los Sures" and still living in NYC. Finally, we present

1 University of Texas at El Paso (UTEP). Full-time lecturer and academic researcher in the Sociology and Anthropology Department since August 2017. Courses taught: Cultural Anthropology; Drug Use Abuse Trafficking; Ethnographic Methods; Anthropology of the Caribbean and Puerto Rico's Society.

2 University of Texas at El Paso (UTEP). MA student in Sociology \& Anthropology. Her research focuses on minorities' disparities and inequalities in El Paso; thesis focalized on Police and Border Patrol brutality against minorities in El Paso.

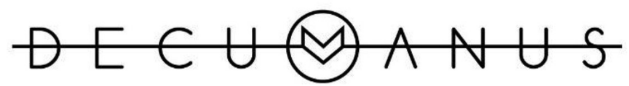

REVISTA INTERDISCIPLINARIA SOBRE ESTUDIOS URBANOS 
a critical reflection on the poverty, welfare State policy, and shed light on the difficulties faced by Puerto Rican migrants and their struggle to preserve the Puerto Rican legacy in the now NYC and gentrified "Los Sures".

Keywords: Nuyoricans; ${ }^{3}$ gentrification; urban studies.

\section{Resumen}

En el siguiente artículo se presenta una reflexión antropológica e histórica sobre el popular barrio pobre de puertorriqueños conocido como "Los Sures" en South Williamsburg, Brooklyn, Nueva York. A nivel teórico, en el artículo se discuten una serie de investigaciones académicas centradas en los siguientes conceptos: pobreza, Estado benefactor, dependencia del Estado benefactor y el impacto de la gentrificación urbana en este barrio popular. A nivel empírico, en el artículo se presenta una reflexión etnográfica basada en experiencias de campo y entrevistas realizadas a exresidentes de "Los Sures" y que aún viven en la ciudad de Nueva York. Finalmente, se presenta una reflexión para comprender las dificultades de los inmigrantes puertorriqueños, la construcción de la identidad comunitaria y la lucha actual por preservar el legado de los boricuas 4 ante el proceso de remodelación urbana conocido como gentrificación en los barrios pobres de Nueva York.

Palabras clave: Nuyoricans; gentrificación; estudios urbanos.

\section{Introduction}

In memory of Ana Meléndez (1932-2010) (Abuela Ana), a brave Puerto Rican single mother who raised five children and lived in "Los Sures" from 1973-1985 and suffered all the vicissitudes in this neighborhood, such as poverty, drug violence, harassment, robberies, and poor housing conditions.

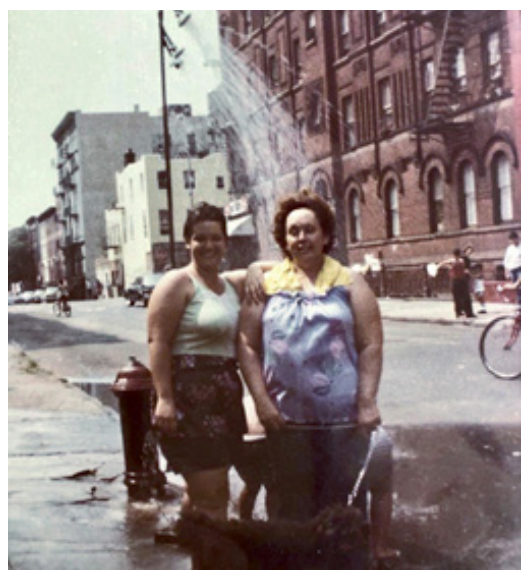

Dr. Victor Vazquez's mother, Carmen L. Rodríguez, and Grandma Ana Meléndez (Abuela Ana), Summer of 1983, Los Sures, Brooklyn, NYC.

3 Nuyorican is a term that refers to the Puerto Rican who were born and raised in New York City. 4 The term "Boricua" refers to the Puerto Rican who were born and raised in the island of Puerto Rico.

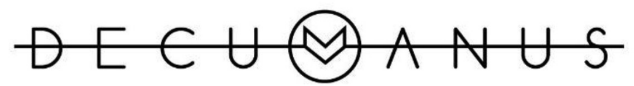

REVISTA INTERDISCIPLINARIA SOBRE ESTUDIOS URBANOS 
The following article presents an anthropological and historical reflection on the Puerto Rican inner-city neighborhood better known as "Los Sures" in South Williamsburg, Brooklyn, New York City (NYC). "Los Sures" is a Puerto Rican community that exemplifies the difficulties and dysfunctional environment experienced in impoverished and segregated neighborhoods within Brooklyn. "Los Sures" represents the iconic image of migrant slums serving as hometowns for thousands of Puerto Ricans that migrated to NYC from the 1930s through the 1970s. Nowadays, "Los Sures" no longer represents the struggling Puerto Rican migrant slums, but the eradication of historical Nuyorican heritage replaced by white upper-class amenities through gentrification.
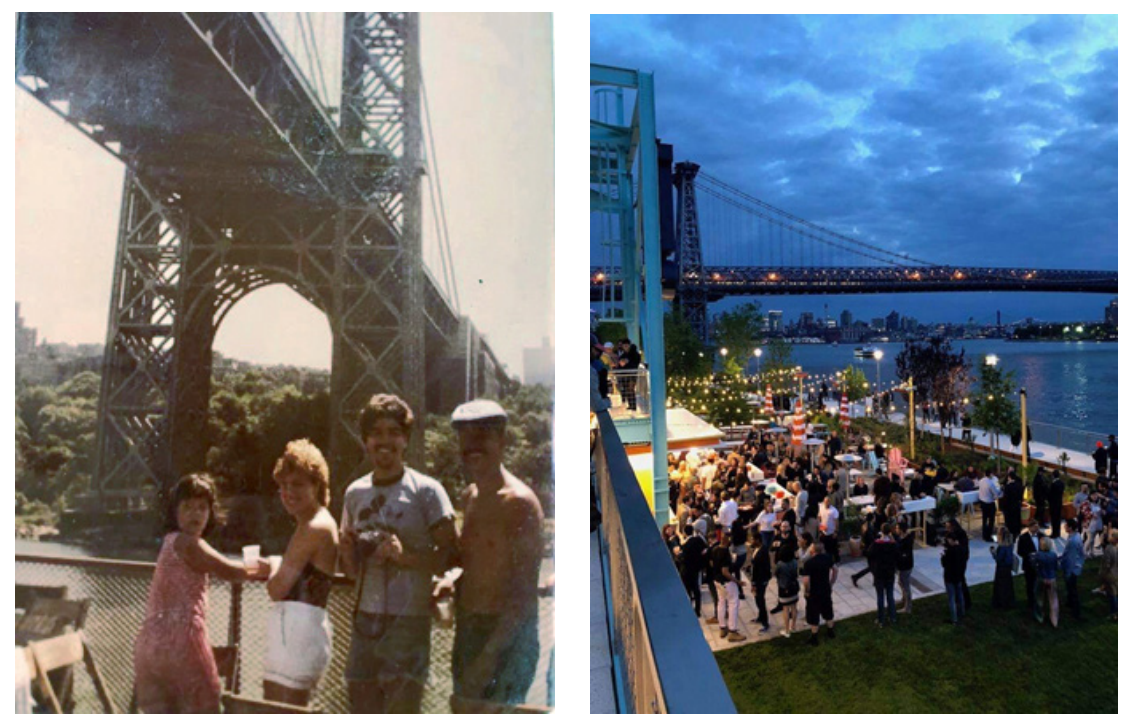

The photo on the left is of Dr. Victor Vazquez's family vacation in "Los Sures" in 1983 gathered under the iconic Williamsburg bridge. The photo on the right depicts the new waterfront view of the Williamsburg bridge with new bars \& restaurants for its new wealthy residents in 2021.

Theoretically, this article explores the contemporary academic discussion regarding the following concepts: the welfare State policy and the inner-city condition discussed by Philippe Bourgois (1998), gentrification impact by Conrad Phillip Kottak and Kathryn Kozaitis (2012), and the discourse surrounding the poverty discussed by Loïc Wacquant (2009). Methodologically, the article presents an ethnographic reflection based on fieldwork experiences and interviews conducted on residents of the previous "Los Sures" and still living in NYC.

Finally, the article reflects on the difficulties of Puerto Rican migrants, the construction of the Puerto Rican identity and community, and the current struggle to preserve the Puerto Rican legacy of the now gentrified "Los Sures." The conclusion focuses on understanding the difficulties of the Puerto Rican migrant experiences of being poor in the most expensive city in the United States. Additionally, we analyze a brief background impact of gentrification process in the 1990s and the current context which has resulted in the dramatic change of living conditions for Nuyoricans.

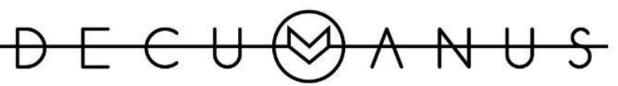

REVISTA INTERDISCIPLINARIA SOBRE ESTUDIOS URBANOS 


\section{A brief historical background of the Puerto Rican mass migration to New York City}

After the Spanish-American war in 1889, Puerto Rico became a U. S. Territory as a result of the United States' victory over the Kingdom of Spain. During the $20^{\text {th }}$ century, the implementation of the Jones Act altered the political climate of Puerto Rico, granting U. S. citizenship to habitants while excluding equal political representation of the island. According to Jorge Duany (2017), this law did not recognize all rights of these new Puerto Rican U. S. citizens, including a lack of full judicial process, limited congressional voting participation, required draft for the U. S. military, exempt from paying federal income taxes, State-side presidential voting, and implementation of the welfare policy with other implementations still in effect today (Duany, 2017). In the 1930s, there was a campaign to push for Puerto Rican mass migration to the United States, particularly to the East coast. The intention was to provide job opportunities to support the working-class experiencing poverty and high unemployment rates after the agricultural economic collapse in Puerto Rico.

This period is better known as the "Great Migration" occurring between the years 19301964 representing the pillar of the Puerto Rican diasporic community in the U. S. This was one of the largest airborne migrations in U. S. history as thousands of Puerto Ricans arrived by commercial airlines in search of better economic opportunities, including wage-labor positions in factories, the agricultural sector, and U. S. infantry positions. Most of those migrants were of a lower socioeconomic index and previously displaced from the job market in Puerto Rico.

After 1952, the exodus exponentially increased as Puerto Rico was declared a Commonwealth of the United States. In the following decades, many Puerto Rican migrants settled in the most impoverished and segregated communities in metropolitan areas, including NYC, New Jersey, Chicago, Boston, and Philadelphia. According to Duany (2017), this diaspora historically concentrated in these urban areas which dramatically altered the urban context of the traditional ghettos in the U. S. For instance, NYc became an extended home for Puerto Rican migrants, creating the "Nuyorican" culture which is the cultural fusion of both New York citizens and Puerto Ricans migrants. This demonstrates their official identity within the U.S. and as a result they established roots for vibrant communities that allowed for the preservation of their culture and political activism demanding equal living conditions and representation during this period of racial tension.

During the 1950s throughout the 1970s, American academics began developing a new approach to the anthropological study of urban poverty to understand the main issues within segregated communities. The growth of Puerto Rican inner-city neighborhoods and the creation of multiple ghettos within NYC demanded the attention of American sociologists and anthropologists focusing on urban studies who utilized a community-based approach (Al-Zubaidi, 2010). Puerto Rican migrants and Nuyorican populations represent a fundamental role in the historical development of these newfound approaches to understand the dynamics of ghettos. The discussion of impoverished populations living in ghettos became the epicenter of anthropological research in the U. S. with the highlighted work of Oscar Lewis' "culture of poverty" viewing this form of life independently

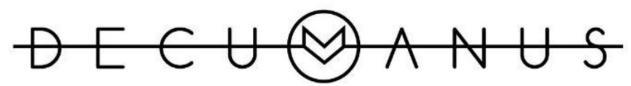

REVISTA INTERDISCIPLINARIA SOBRE ESTUDIOS URBANOS 
from political and economic factors. Opposing scholars such as Charles Valentine argued against Lewis' stigmatization of impoverished populations such as Puerto Rican migrants and Nuyoricans demanded a new perspective in understanding the subculture of poverty. Half a century after Lewis' "culture of poverty", Puerto Rican scholars still refute this stigmatized approach to Puerto Rican perception. Nowadays, many Nuyorican artists are focused on changing the tainted reputation instituted during the "Great Migration" that stereotyped Puerto Rican migrants and the Nuyorican populations. These artists highlight the Nuyorican culture that emphasizes the repercussions of stigmatization of poor LatinX and Puerto Ricans while allowing for a newfound appreciation of Nuyorican contributions to urban multiculturalism. For example, the contemporary Nuyorican artist Lin-Manuel Miranda offers a new perspective of the Nuyorican image emphasizing the historical achievements, including their cultural heritage, communal ties, social mobilizations, and political presence in NYC. Additional efforts to highlight the struggles of Nuyoricans include the utilization of murals honoring the Puerto Rican heritage and migrant experiences. More ahead, we will explain the utilization of these murals representing an act of protest to demand respect for Nuyorican residents experiencing the effects of gentrification on these historic communities. Furthermore, we will explain how the Nuyorican struggle allowed other LatinX communities to gain mainstream acceptance within the U.S.

\section{Anthropological analysis on "Los Sures," Williamsburg, Brooklyn and the Nuyoricans lived experience}

To provide an ethnographic description of the living conditions seen in "Los Sures," we analyze the historical documentary of Los Sures (1984) providing a detailed representation of the struggles of poverty and the informal economy in this neighborhood. We also offer a brief description of conducted interviews of Nuyoricans residents raised in this community throughout the 1970s and 1980s, and their explanation of the impacts of gentrification on the historical "Los Sures."

\section{Puerto Rican invasion of Williamsburg, Brooklyn}

During the "Great Migration," the Puerto Rican diaspora represented an influx of the fundamental working class of unskilled workers. As the migrants settled into segregated and cheap neighborhoods, they invaded Jewish and Italian positions within factories and construction work, residing in areas such as East Harlem, Lower East Side, The Bronx, and Brooklyn, particularly Williamsburg. This massive population shift in these areas resulted in the Puerto Rican migrants being one of the most disadvantaged groups, becoming the second-largest minority group in NYC and the second-largest Hispanic population in the U. S. After the fled and closed of factories, and the NYC economic and fiscal crisis in the 1970s, the lack of job opportunities resulted in these working-class communities of socially marginalized populations being further and segregated from mainstream society (Bourgois, 1998). This enabled these jobless communities to transform into inner-city or

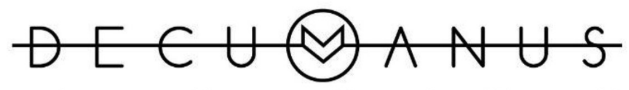

REVISTA INTERDISCIPLINARIA SOBRE ESTUDIOS URBANOS 
welfare communities seen in "Los Sures," a neighborhood that became a sizable Puerto Rican ghetto after the NYC economic collapse.

\section{How does it feel to live in "Los Sures?"}

The neighborhood colloquially known as "Los Sures" is located in South Williamsburg, Brooklyn. The historic Jewish sector was invaded by Puerto Rican migrants in the 1950s, due to its cheap housing. The name "Los Sures" originates from the Puerto Rican community, translating the Spanish slang to "The Southern." This represents the contrived identity of this community that lives within the Nuyorican's imagination, providing a unique location for Puerto Rican identity within the urban context of NYC. Diego Echeverria's documentary of Los Sures (1984) explains the effects of poverty on the Nuyorican neighborhood while highlighting survival methods, including a culture of welfare reliance and informal economics such as drug trafficking, car theft, and illegal street vending.

According to the Architectural League of New York, organizations discovered the last living copy of the $16 \mathrm{~mm}$ film Los Sures and following its restoration by the community organization UnionDocs. Within the iconic atmosphere of the $80 \mathrm{~s}$, known for breakdancing boomboxes and romanticized drug usage, the poor neighborhood of "Los Sures" maintained cultural elements of religious practice, salsa music, gastronomy, and Puerto Rican values (Urban Omnibus, 2014). Therefore, this illustrates the microcosm of marginalized Puerto Rican culture and history fused with the NYC urban environment and lack of job opportunities. The documentary highlights the multitude of issues faced by the migrant community and speaking to the resilience of its residents struggling to survive, even today.

In our analysis, the documentary discusses the stories of five Nuyorican and their daily struggle to survive the conditions of inequality. Starting with the 20-year-old father and car thief, Tito. He discusses the living conditions and influence of "Los Sures" on his life path to becoming a criminal without consideration for his consequences. He introduced the discourse of "easy money" 5 as a method of the informal economy to survive in "Los Sures." Next, we are introduced to Marta, an unemployed welfare recipient and single mother of five children solely reliant on food stamps. She described the difficulties in raising five female children in the ghetto, speaking to the negative influence associated with welfare communities, and the potential future of her children. Next, we are introduced to Ana María, a Puerto Rican migrant, proudly reliant on welfare aid enabling her to support her seven children. She represents the iconic Puerto Rican Catholic devotee, expressing the role of faith to survive the conditions of "Los Sures." However, Ana Maria expressed her interest to participate in the spiritism cult to communicate with her late son, who was murdered in "Los Sures." The documentary presents a scary cult-like segment of the spiritism or mediumship practiced by Nuyoricans and capturing the moment when Ana María contacted her late son. The anthropological significance of this scary moment stresses the cultural ties of Nuyoricans and their religious affiliations, and the significance of

5 "Easy money" is a popular phrase within the U. S. for individuals who obtain money or profit in the informal economy.

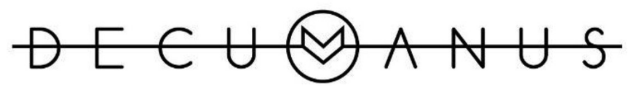

REVISTA INTERDISCIPLINARIA SOBRE ESTUDIOS URBANOS 
faith in their customs. The public displays encompass the Puerto Rican expressiveness within their religious practices, containing euphoric and energetic performances of their cult-like services seen in the streets of "Los Sures." Next, we are introduced to the character of Cuso, who represents the typical Puerto Rican migrants seen in the 1940s "Great Migration." Compared to others, Cuso outwardly expressed pride for living in "Los Sures" despite the negative stigma maintaining his refusal for welfare aid. Cuso represents a First-Generation of Nuyoricans bilingual entrepreneur, who maintained his ethic based of work and dedication to obtain the American Dream.

Lastly, we are introduced to Evelyn, the most educated person in this documentary. She was able to obtain a college education and properly speak both English and Spanish. She discussed the challenges associated with living in "Los Sures," emphasizing the dynamics of this dysfunctional community and the importance of the informal economy of drugs. Evelyn presents the possibility of hope for success from these conditions with her refusal of welfare culture and philosophy for hard work. Also, she was an active leader in her community, where she educated and helped others experiencing difficulties in "Los Sures." In conclusion, this documentary serves as a participant observation exercise to understand the hardship associated with living in a ghetto, all while capturing the Puerto Rican experience to overcome poverty and a lack of opportunities in "Los Sures."

Furthermore, we provide additional experience from a survivor of "Los Sures," Liz Marrero. She is a living relative and cousin of Dr. Victor Vazquez, where she currently resides in NYC. After conducting an interview, Liz offered us details elaborating on her childhood experience of growing up in "Los Sures" and her ability to overcome the marginalizing atmosphere. Initially, we asked her to describe her overall experience as a child and to provide a description of the daily life of her family in "Los Sures." In her voice, Liz provides a vivid image of "Los Sures:"

I was raised in Brooklyn, NY in an area named "Los Sures". Growing up in "Los Sures," I learned to be tough and although I was not the type of kid to play in the streets without my parents being there, I learned to be street smart. At that time, I lived with my parents and two siblings. The only other family I had near was my Grandmother and Great Aunt. My mom was a factory worker, and my Stepdad was a Merchant Marine and was gone for months at a time. He would return with goodies from around the world, which taught me there was a world outside of what was the ghetto back then. Life in "Los Sures" was unsafe and very difficult. Many gangs were fighting with each other. The difference between gangs back then and now is that back then they only targeted who they were looking for. They would protect everyone else. Today, they hurt everyone. I recall a particular gang wanting to bomb the store next to our building; they escorted everyone out of the building before they set the building on fire. Gang members carried me down the stairs. They helped people they did not have beef (problems with). It could be a normal day in your home and suddenly you would hear hard knocking on the doors with people yelling Fire! Fire! And we would have to run out of the building at a moment's notice. Drugs were everywhere. Glue sniffing was very popular in the 70s and 80s. I would look out my window and there were people sniffing glue out of paper bags. Although I knew it was bad and wrong to do drugs, it seemed normal to see it everywhere. I attended

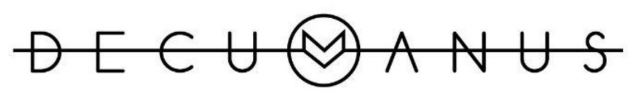

REVISTA INTERDISCIPLINARIA SOBRE ESTUDIOS URBANOS
Núm. 7. Vol. 7. Mayo 2021-Octubre 2021. Instituto de Arquitectura, Diseño y Arte. Universidad Autónoma de Ciudad Juárez. ISSN: 2448-900X 
elementary and middle school in Williamsburg. I then attended high school far away near Coney Island. I was never afraid to step out of the neighborhood to experience new things. I had amazing teachers, particularly in elementary school. They spoke my language and understood my culture. I moved to $P R$ for a brief time and returned to the same neighborhood and the school was supportive.

Liz's memories of "Los Sures" reflect the analysis of Philippe Bourgois (1998) regarding the dynamics of the inner-city. Bourgois' ethnographic research was conducted on the resistance and self-destruction seen within inner-city street culture, centralized on East Harlem, aka the Spanish Harlem, a similar iconic Puerto Rican ghetto in the 1980s and 1990s. The street culture of inner cities, according to Bourgois (1998), is composed of a "...complex and conflictual web of beliefs, symbols, modes of interaction, values, and ideologies that have emerged in opposition to exclusion from mainstream society". These aspects are compounded by the "cultural assault" experienced when marginalized people experiencing extreme poverty while situated within the richest city in the U. S. Liz's experience reflects the aspects of the street culture present within Bourgois' research. We need to note the perseverance of many "Los Sures" residents similar to Liz, who did not succumb to the degradation of street culture. These difficulties of Liz's childhood provided her with the strength to persevere the conditions of "Los Sures," becoming successful in her endeavors.

Another vital experience discussed by Liz is that of urban change. She provides her perception regarding the impact of gentrification on "Los Sures:"

Puerto Ricans faced many challenges. To cope, they relied heavily on community organizations rooted in traditional family morals. Various city-wide issues led to despair in the area, and as a result, the community began to suffer from unemployment, drug abuse, crime, disease, and an increased school dropout rate. A lack of public services such as firehouses and a police precinct made the existing issues even worse.

The neighborhood has recovered from the issues of the $1960 \mathrm{~s}$, but they continue to lose the Puerto Rican community. Although I moved out of the neighborhood almost thirty years ago, my mother currently lives there. The neighborhood has changed drastically over twenty-five years, there were more empty lots than buildings. The abandoned buildings that were boarded up were where people went to do drugs. Today, there are no empty lots and new developments. Old buildings have been knocked down and rebuilt.

It is important to note that the timeframe of Liz's response is situated during the 1980s and 1990s fiscal crisis, when Nuyorican residents fled to New Jersey, Philadelphia, Florida, and Puerto Rico seeking affordable housing and job opportunities.

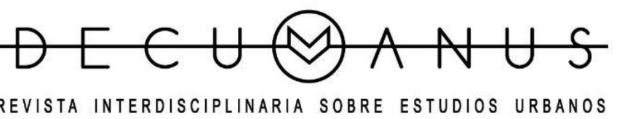

REVISTA INTERDISCIPLINARIA SOBRE ESTUDIOS URBANOS 


\section{The impact of gentrification in "Los Sures"}

From the 1990s until now, the combination of NYc's fiscal crisis and rampant private developers created the perfect storm to displace Nuyoricans. This resulted in the abandonment of the traditional poor neighborhoods, including East Harlem, Lower East Side, The Bronx, and Brooklyn. Private developers took advantage of this fiscal crisis and began buying the poor abandoned housing. Thus, increasing the neighborhood value. This process has contributed to making NYC the most expensive city in the U. S. and altering the original identity of the migrant communities. Kottak and Kozaitis (2012) discuss the phenomenon occurring in urban environments within the context of globalization. The location of urban environments and the housing inequities they contain are perpetuated by the market. This phenomenon is known as gentrification, which entails the purchase and "revitalization" of abandoned and low-income housing by upper-class people and developers. In this urban renewal process, developments aimed at structural improvements result in higher property values that attract wealthy residents and businesses. Low-income residents are forced out of their neighborhoods, losing access to jobs, public transportation, and schools. Therefore, gentrification offers urban diversification and renewal at the cost of reinforced racism and classism (Kottak, \& Kozaitis, 2012).

In this sense, "Los Sures" represents an example of gentrification and its effects over three decades. Today, South Williamsburg is no longer the inner-city presented in Echeverria's documentary or the ghetto seen in Liz's childhood memories. This neighborhood offers standard \$14 cocktails and one-bedroom apartments with scenic views of downtown Manhattan and the Williamsburg bridge with affordable prices ranging from $\$ 500,000-\$ 1,000,000$.

To preserve the historic struggle of Nuyorican heritage, a group of activists including architects, urban anthropologists, and urban artists strives to communicate the living conditions experienced by the original Nuyoricans residents of the now-gentrified Williamsburg. One example being the UnionDoc project “Living Los Sures", directed by Christopher Allen and others, present a multifaceted project based on the Southside living experience, including the historical legacy of "Los Sures." Members of the community produce events to provide city council members and planners better understanding of communities faced by gentrification and the cultural heritage associated with specific areas. The current project aims to portray the rich history of these neighborhoods, relying on the 1984 documentary that captured the stories of community members (Urban Omnibus, 2014).

According to Liz, she states the influence of "yuppies" ${ }^{6}$ altered the lifestyle of "Los Sures" as follows:

Los Sures" is no longer the Puerto Rican neighborhood it used to be. There is none of that today. Some areas have tried to continue the tradition of having their block parties and they still get a great turnout. Some people come from other states to see their

6 "Yuppie" is a slang used by Nuyoricans to describe the young and wealthy white elites that began to take over Williamsburg during the process of gentrification.

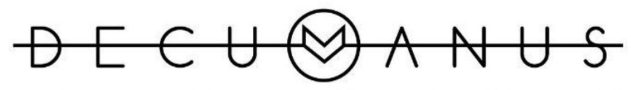

REVISTA INTERDISCIPLINARIA SOBRE ESTUDIOS URBANOS 
old friends. However, they no longer come easily. The new residents ("yuppies") notify the police because the music is too loud in the middle of the day. Yet, they can have their rooftop parties all night, and no one complains. The older people have passed, and their children have left the neighborhood. People have been squeezed out of the neighborhood due to the high rent and the homeowners have sold them for pennies so they can rebuild. Where there was a 4-family house is now a 20+ building. A good friend of mine regrettably sold his apartment for $\$ 5,000$, which is now worth $\$ 200,000$.

Finally, this process of gentrification has created urban tension in South Williamsburg perpetuating the ethnic and class segregation between "yuppies" and the original Nuyoricans. In our fieldwork, the physical changes of the urban context and environment are evident to non-residents. During the 1980s, the Puerto Rican culture of "Los Sures" community was so vibrant that stimulated all senses. The smell of Puerto Rican coffee alongside the smell of Cuchifritos and frituras de Puerto Rico wafting from the bodegas. The once jubilant streets of "Los Sures" offered the childhood playgrounds for hopscotch and dancefloors for the art of breakdance and urban performance as well as the availability of open drug usage. Comparatively, the new Williamsburg encompasses NYc's elitist culture with amenities aimed at the professional hipster or "yuppie" populations, erasing the inner-city atmosphere of the 1980s. Our fieldwork stage allowed us to photograph cases that exemplify gentrification seen in "Los Sures" and other Nuyorican communities within Manhattan, specifically East Harlem or Spanish Harlem, and the Lower East Side.

\section{Fieldwork portraying the gentrified "Los Sures" community, Spring of 2021}
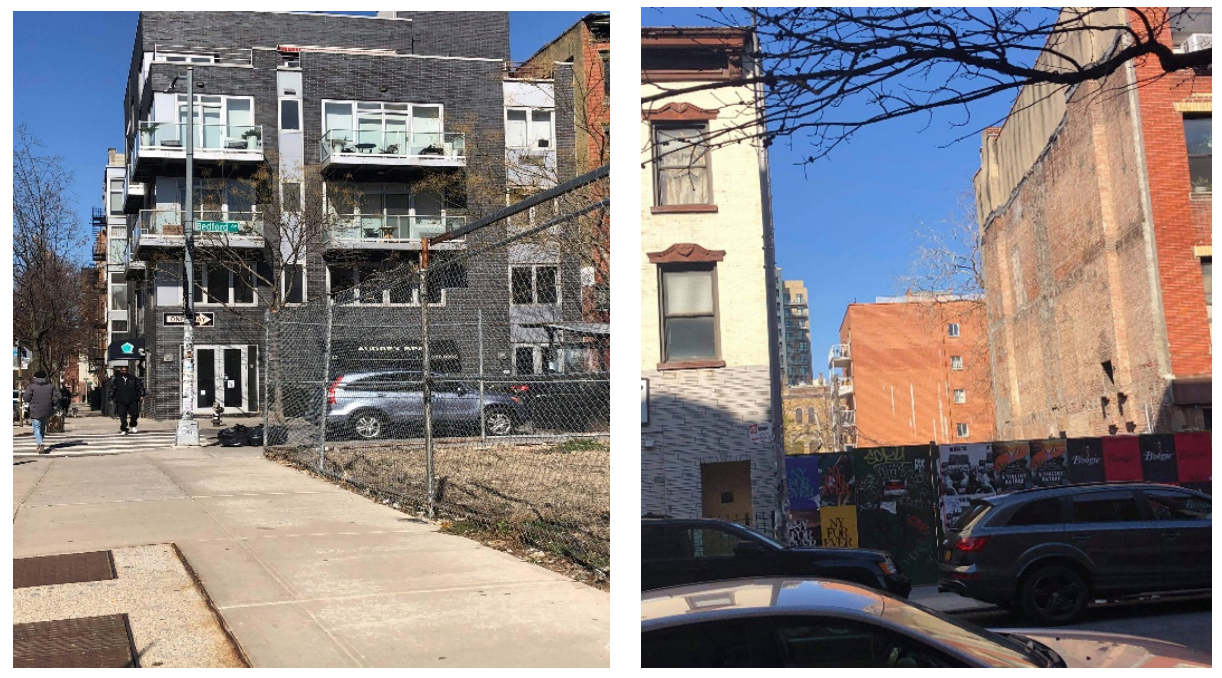

The newly renovated buildings are located in the historical "Los Sures" Avenue: Bedford Ave. These minimalistic designs offer open balconies to experience the surrounding hipster ambience. As prices for real estate rise, low-income residents cannot afford housing in "Los Sures," leaving many empty lots for sale.

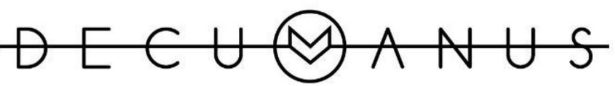

REVISTA INTERDISCIPLINARIA SOBRE ESTUDIOS URBANOS 


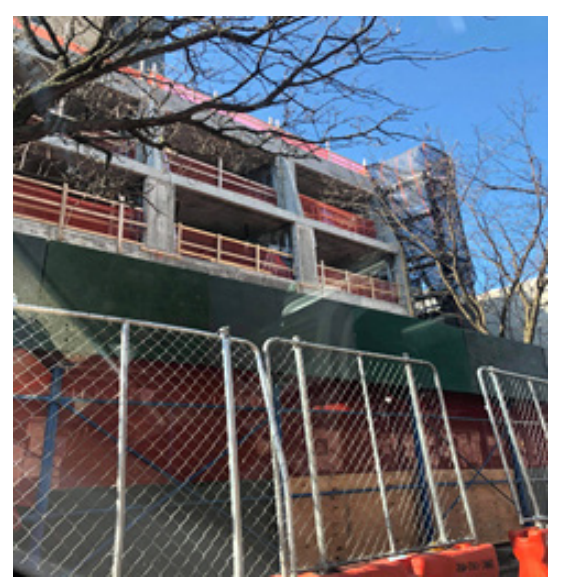

As a result of gentrification, wealthy developers buy and renovate buildings in "Los Sures," with these sights and sounds of construction being a common occurrence over the last twenty years.
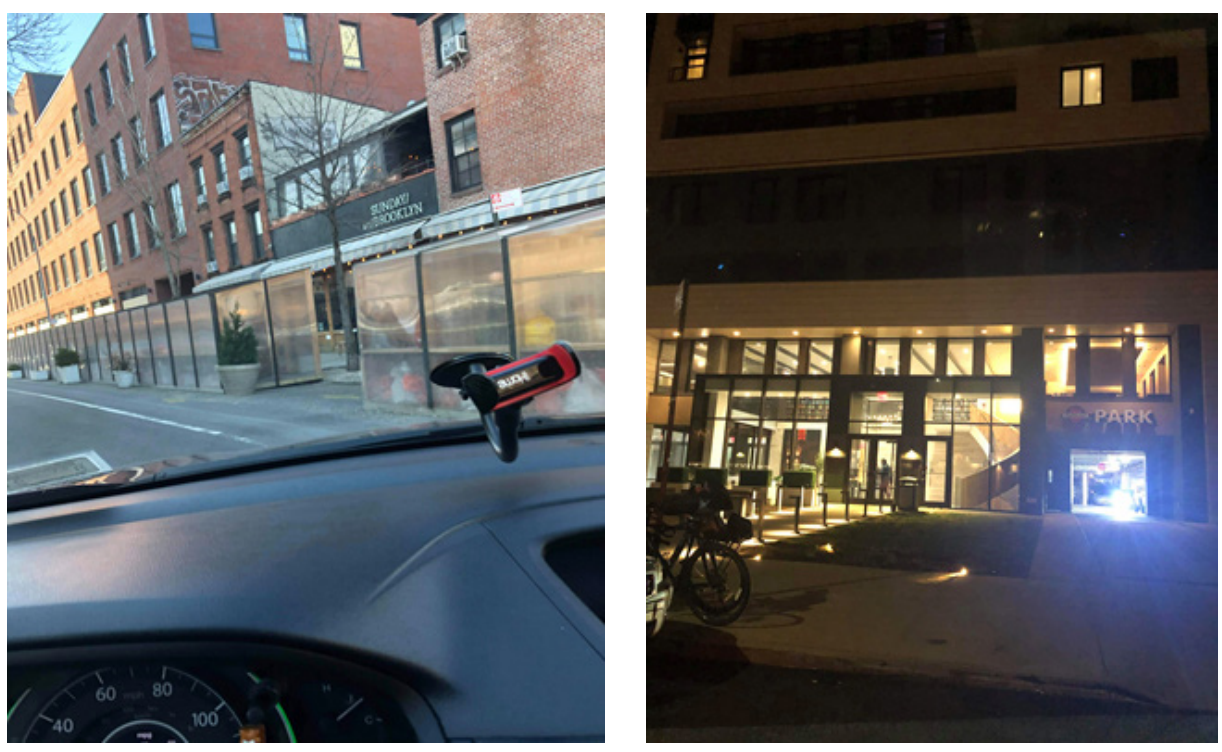

\section{Hipsters vs Nuyorican grafiteros}

The photo on the left depicts graffiti over Sunday in Brooklyn, a popular brunch location. It is an interesting juxtaposition to see the visual act of defiance over the hipster restaurant. The new restaurants and bars replaced the popular Nuyorican Cuchifritos and bodegas. Alongside newly added building entrances and parking lots reflect the gentrification present in Williamsburg.

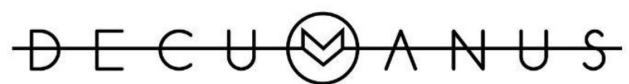

REVISTA INTERDISCIPLINARIA SOBRE ESTUDIOS URBANOS 


\section{Fieldwork in other gentrified neighborhoods in NYC, Spring of 2021}
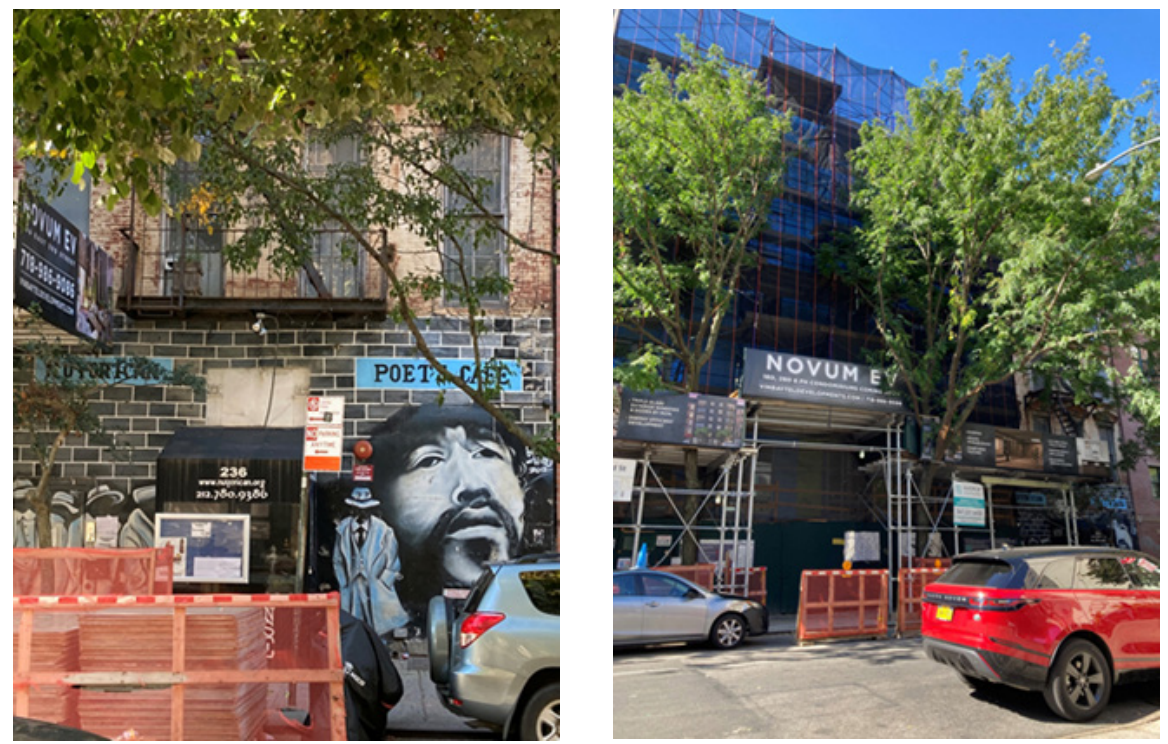

The iconic Nuyorican Poets Cafe, a popular and emblematic Nuyorican bar, is currently under renovations, and Nuyorican mural protest in Lower East Side. Photos by Pastor Crespo (2021).

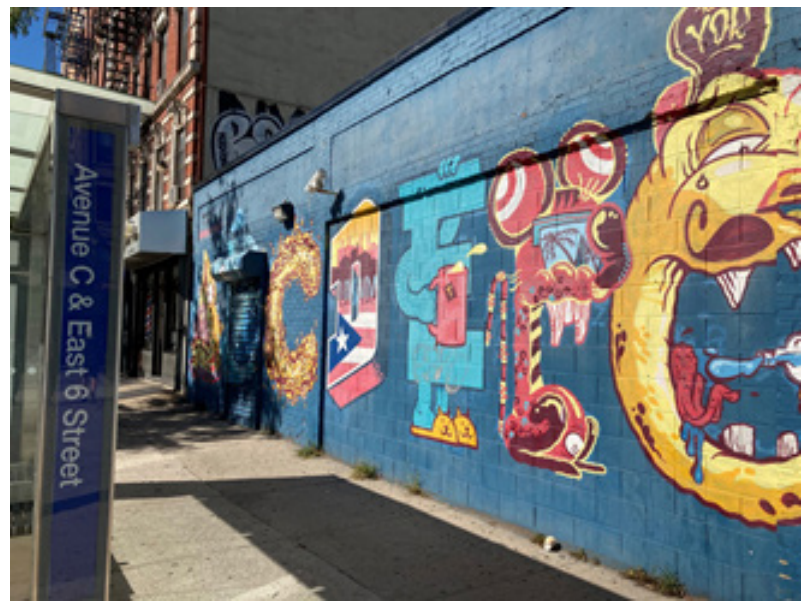

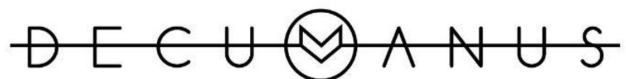

REVISTA INTERDISCIPLINARIA SOBRE ESTUDIOS URBANOS 

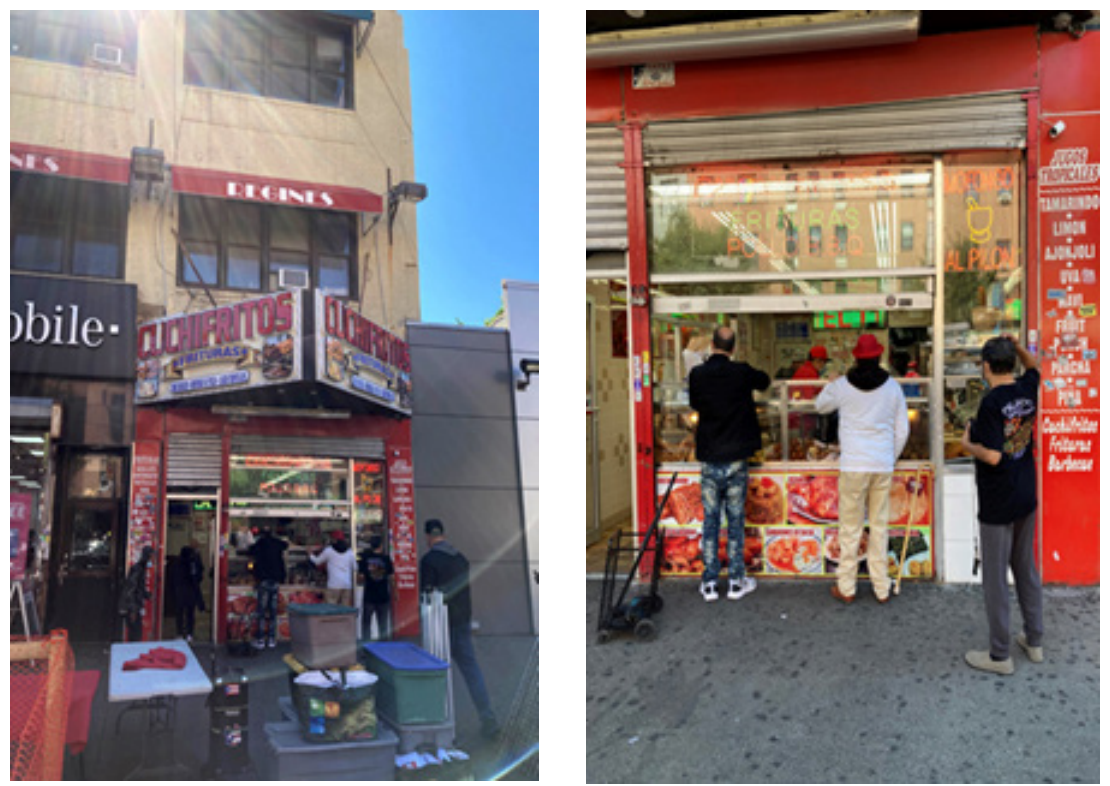

El Barrio in East Harlem known as the "Spanish Harlem", with the common Cuchifritos bodegas facing extinction from the threat of gentrification.
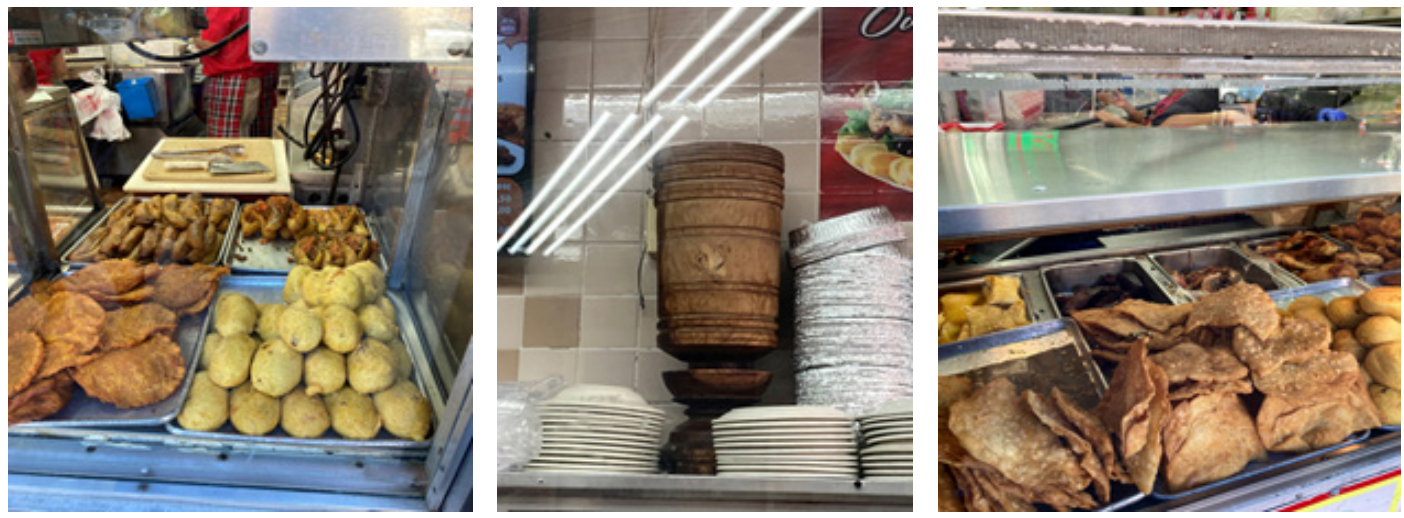

This picture represents the traditional Puerto Rican al pilón, a wooden mortar and pestle used for mashing ingredients to make popular Puerto Rican dishes such as Mofongo. This dish is fried plantains mashed with salt garlic brother and oils, made in the pilón. Photos by Pastor Crespo (2021).

\section{Street side view of La Fonda, a Nuyorican restaurant during COVID-19 restrictions}

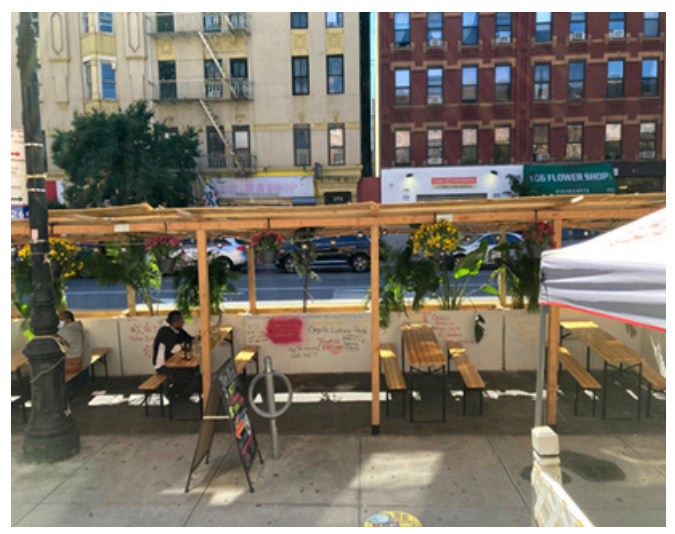

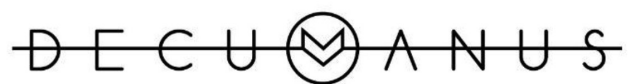

REVISTA INTERDISCIPLINARIA SOBRE ESTUDIOS URBANOS 

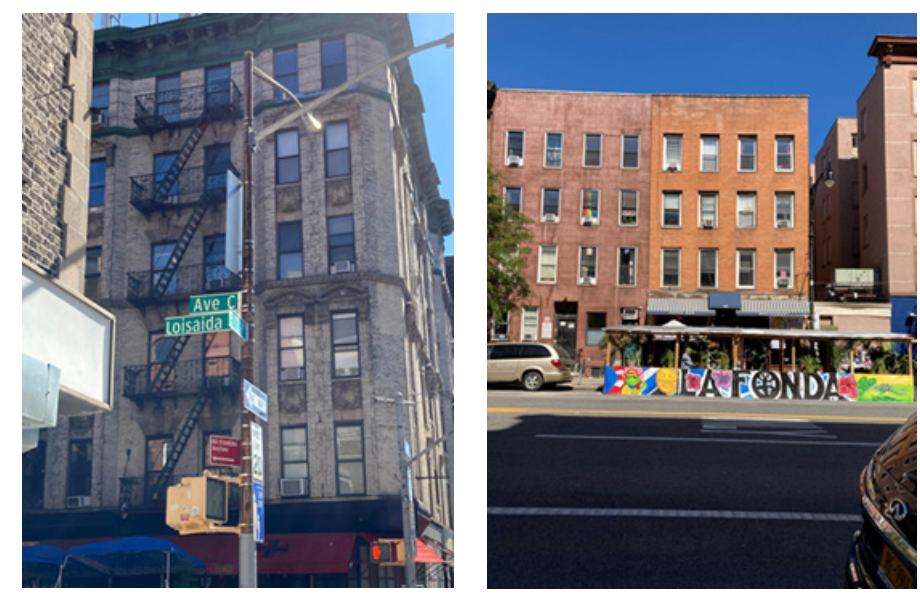

Newly renovated real estate is seen in the Lower East Side with prices driving out low-income residents. Photos by Pastor Crespo (2021).

\section{A brief reflection on the welfare impact in Nuyoricans image}

In the 80 s many people used welfare and food stamps as a way of living in "Los Sures," especially after the main factories left. Welfare is horrible because it creates a reliance on the government. Many kids and teenagers from "Los Sures" grew up in this cycle of dependency and marginalization. Benito Flores response for and interview.

Benito Flores, a retired Nuyorican and previous "Los Sures" resident from the 80 s, can recall the welfare dependency seen in "Los Sures." Currently, he lives in Kissimmee, Florida, where he moved to a popular Puerto Rican neighborhood. Benito describes the welfare policy and its label of social stigmatization to the Nuyoricans in the U. S. For instance, “... in 'Los Sures,' welfare became the only income for many families and many families who used the welfare also contributed to the prejudice against of Nuyoricans, the reputation that we are lazy people who like to be dependent on welfare..." Benito continues:

For that reason, nobody cared about "Los Sures" at that time. The lack of opportunities, and the deterioration of the housing conditions, and the lack of intervention of nyc institutions such as Police, Health Care, Government services. At that time, New Yorkers were aware of the Nuyoricans living conditions and the poor conditions they used to live in. In this city, if you are a welfare recipient you don't have rights. It is like a label that you are inferior and you are destined to live in poor conditions forever. In this country, if you are a welfare recipient you are a loser and you have a derogatory perception from other people. Most Puerto Rican teenagers in those days joined the gangs to survive the poor conditions of "Los Sures." The gangs served as groups who protected us from other African Americans, other Nuyoricans, Dominicans or Latino gangs from other neighborhoods.

Images of welfare mentioned by Benito require emphasis on the conditions of inequality experienced by many Nuyoricans during the "Great Migration" and after as well as the

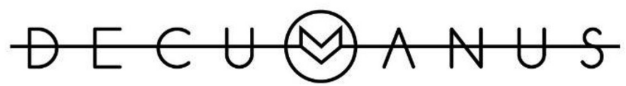

REVISTA INTERDISCIPLINARIA SOBRE ESTUDIOS URBANOS 
government's reaction to urban areas. According to Benito, even the word welfare harbors powerfully derogatory stigmatizations, depicting a stereotypical image of poor minorities and criminals or feel inferior, something experienced by many Nuyoricans. In this sense, the study of urban inequality and poverty offers pertinent discussion regarding the future effects of welfare policy.

According to French sociologist Loïc Wacquant (2009), the welfare policy is influential in developing marginalized neighborhoods in the U. S. Pertinent to our analysis, Wacquant's perspective of the welfare state applies to the Nuyorican experience. Wacquant (2009) states that the residual nature of the welfare state solely responds to both the failures of the market and individuals, awarding those worthy of aid on a case-by-case basis. He claims the paradox of the $U$. S. regarding impoverished minority adults and children is that welfare will only support the bare minimum without proper funding support and education to prevent this perpetual dependency. There is an evident lack of preventative policy implemented in Nuyorican communities, rather they are provided with the bare minimum to maintain the dynamics of urban neighborhoods. The term residual indicates the government's awareness of the market failures without proper investments in policies to protect working conditions that prevent marginalization within the context of neoliberalism. The intentions are to bolster the mechanisms of this perpetuating cycle composed of the unskilled workers in the urban labor market forcing these populations to take on such positions.

Wacquant (2009) also claims the welfare state creates the discourse of criminalized poverty in the U. S., especially of minorities. He states the criminalization of poverty implicates a racial state: The racial state is composed of bureaucratic systems and fields that constantly preserve the social and symbolic divide between whites and minorities, originating during slavery and further perpetuated by the segregation era. In terms of slavery, the welfare policy divides the white middle-and-upper-class from the minority working-class. The expansion of the New Deal in the 1960s: it is argued that this division perpetuated the prominent racial divide in the political system resulting in the deterioration of civil engagement which allowed for the stranglehold of corporations and wealthy funders to control the electoral system (Wacquant, 2009). This perception of the impoverished compounded a class disparity among ethnic groups, particularly within the context of globalized neoliberalism resulting in the deprivation of the U. S. working class.

Retrospectively, the stigma of Puerto Ricans in the U. S. is partially based on a historical reliance on welfare within the island. The realities of welfare have been argued by Puerto Rican scholars who emphasize its longstanding impact on the island's mentality. One of the most popular analyses of Puerto Rico refers to the effects of welfare and its role to perpetuate governmental dependency which promotes welfare as a standard of living, resulting in a Welfare Island. The derogatory image of a poor Puerto Rican society has resulted from the myths of lazy people who enjoy living in these conditions (Vazquez, 2012).

Currently, the COVID-19 pandemic has increased reliance on governmental aid, in some cases becoming the sole hope for survival for thousands of working-class families, particularly Nuyoricans and other minorities. Urban areas such as Brooklyn were impacted

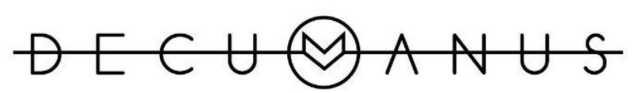

REVISTA INTERDISCIPLINARIA SOBRE ESTUDIOS URBANOS 
by the pandemic, largely affecting the struggling working-class residents, experiencing effects from both the virus and the labor market.

\section{Final reflections: The search for an inclusive NYC}

The dramatic changes seen in these historic poor neighborhoods in NYC are noteworthy for anthropologists and urban architects. The renovated apartments add newfound desirability to the aesthetic of South Williamsburg no longer representing the endeavors of "Los Sures." The perspective, as one walks from Williamsburg Avenue through Bedford Avenue, includes the revamped atmosphere built for its modern residents. Interestingly, the smell of weed wafting from the unrecognizable structures reminds us of the urban context and how it has changed within the last four decades. This process promotes the influx of exclusive residents who can achieve this exceptional lifestyle. Undoubtedly, gentrification has improved the conditions in terms of infrastructure within the inner-city neighborhoods of the once Nuyorican communities. The lucky residents of "Los Sures", who owned real estate in the $80 \mathrm{~s}$, now hold a small fortune in the developing South Williamsburg, coupled with the threat from corporate and private developers continuously harassing residents to purchase the property that forces out low-income residents. The gentrification seen across NYC indicates the shift to an elite population as working-class residents are forced to relocate to affordable neighborhoods in Bushwick, Brooklyn. Now the struggle for poor residents is very evident as they search for decent areas in NYC.

This process has resulted in the forced displacement of thousands of Nuyoricans, Latinxs, and other poor minority people from these historically impoverished communities. The sole positive impact for those residing in these new luxury apartments includes the lack of marginalization experienced in places like "Los Sures." The intense climate of rampant crime was displaced alongside the systematic process of removing original citizens by institutions of power implemented without the knowledge and consent of community members. Consequently, the crime and violence of the informal economies from impoverished communities have migrated alongside its residents to other poor areas such as Kensington, Philadelphia; Camden, New Jersey; and Kissimmee, Florida.

The accumulation of different effects including the economic market, social dynamics, and governmental institutions are responsible for urban tension and discomfort of the Nuyoricans. Together, activists and community organizations are currently fighting to demand civic participation in community developments to preserve their Puerto Rican heritage. Since 2011, Andrew Mark Cuomo has served as the governor of New York, gaining popularity among the citizens with his reactions to the COVID-19 virus. Despite his public approval, he is currently facing serious sexual harassment allegations that overshadow the issues faced by gentrified communities. In August 2021, Mayor Cuomo presented his resignation after an intense campaign against his sexual scandals. After that event, Kathy Hochul became the first women governor of NYC. On the other hand, the Mayor of New York City, Bill de Blasio, since 2014, sold the public image of his support for poor minority communities, yet his actions demonstrate the support for developers and urban renewal in a city that openly embraces neoliberalism. Our hope through this article is to provide

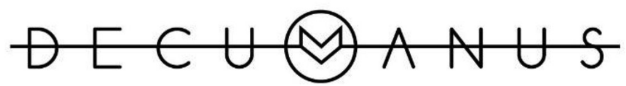

REVISTA INTERDISCIPLINARIA SOBRE ESTUDIOS URBANOS 
visibility to the struggling Nuyorican and minority communities who deserve an inclusive NYC.

\section{Acknowledgments}

We would like to thank those who participated in the interview process making this article possible. Thank you both Liz Marrero and Benito Flores for your cooperation and openness. Also, we would like to thank Pastor Crespo for his role in the fieldwork phase, and Julia Holguin in the process of final edition.

\section{References}

Al-Zubaidi, L. (2010). Urban Anthropology: Contemporary Issues Methodology Sources Web Link. Kultúra és Közösség. http://www.kulturaeskozosseg.hu/pdf/2010/1/kek_2010_1_12. pdf

Bourgois, P. (1998). In Search of Respect. Selling Crack in El Barrio. Cambridge University Press.

Duany, J. (2017). A Stateless Nation in Puerto Rico: What Everyone Needs to Know. Oxford University Press.

Echeverria, D. (Director) (1984). Los Sures 1984 [Film]. Union Docs.

Kottak, C., \& Kozaitis, K. (2012). On Being Different. Diversity \& Multiculturalism in the North American Mainstream. McGraw-Hill.

Roche, D. (2021, February 18 ${ }^{\text {th }}$ ). How Long has Andrew Cuomo Been New York Governor and When Is He Up for Re-election? Newsweek. https://www.msn.com/en-us/news/ politics/how-long-has-andrew-cuomo-been-new-york-governor-and-when-is-he-upfor-re-election/ar-BB1dNwnP

Shaw, R. (2017). NYc's “Progressive” Mayor Bill de Blasio Promotes Gentrification, Displacement. Beyond Chron. https://beyondchron.org/nycs-progressive-de-blasio-promotes-gentrification-displacement/

Urban Omnibus (2014, January $4^{\text {th }}$ ). Living “Los Sures", Past and Present. Urban Omnibus. https://urbanomnibus.net/2014/10/living-los-sures-past-and-present/

Vazquez Rodriguez, V. M. (2012). Estudio etnográfico de la comunidad de Los Chorros en Guaynabo, Puerto Rico [Tesis]. E-Prints Complutense (ucm.es).

Wacquant, L. (2009). Punishing the Poor: The Neoliberal Government of Social Insecurity (Illustrated ed.). Duke University Press Books.

Yee, V. (2016, May $\left.5^{\text {th }}\right)$. Gentrification in a Brooklyn Neighborhood Forces Residents to Move On. The New York Times. https://www.nytimes.com/2015/11/29/nyregion/gentrification-in-a-brooklyn-neighborhood-forces-residents-to-move-on.html

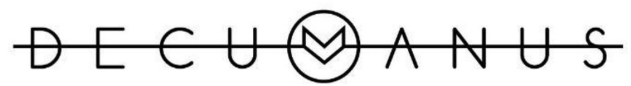

REVISTA INTERDISCIPLINARIA SOBRE ESTUDIOS URBANOS 